\title{
A CENTURY OF VIOLENCE IN A RED CITY
}





\section{A CENTURY OF VIOLENCE IN A}

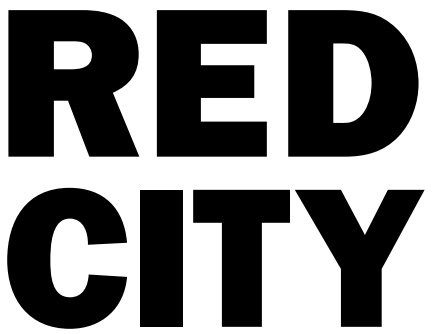

Popular Struggle,

Counterinsurgency, and Human Rights in Colombia

\section{LESLEY GILL}

DUKE UNIVERSITY PRESS

Durham and London 2016 
(C) 2016 Duke University Press

All rights reserved

Printed in the United States of America on

acid-free paper @

Designed by Amy Ruth Buchanan

Typeset in Chaparral Pro and Franklin Gothic

by Tseng Information Systems, Inc.

Library of Congress Cataloging-in-Publication Data

Gill, Lesley, author.

A century of violence in a red city : popular struggle, counterinsurgency, and human rights in Colombia / Lesley Gill.

pages $\mathrm{cm}$

Includes bibliographical references and index.

ISBN 978-0-8223-6029-2 (hardcover : alk. paper)

ISBN 978-o-8223-606o-5 (pbk. : alk. paper)

ISBN 978-o-8223-7470-1 (e-book)

1. Human rights - Colombia - History - 2oth cen-

tury. 2. Working class-Colombia-History-2oth

century. 3. Labor disputes-Colombia-Barran-

cabermeja-History-2oth century. I. Title.

JC599.C7G55 2016

$986.1^{\prime} 25-\mathrm{dc} 23$

2015026279

Cover design: Jenni Ohnstad 
IN MEMORY OF MY

MOTHER, JOAN GILL

(1927-2012) 
